\title{
Gênero e ciência: a carreira científica de Aída Hassón-Voloch*
}

\author{
Nara Azevedo, Bianca Antunes Cortes, \\ Luiz Otávio Ferreira, Magali Romero Sá**
}

Com o objetivo de identificar a presença $e$ a contribuição acadêmica das mulheres cientistas, vis-à-vis a de seus colegas homens, na construção da história de três das mais importantes instituições de pesquisa localizadas na cidade do Rio de Janeiro Instituto Oswaldo Cruz, Museu Nacional e o Instituto de Biofísica iniciamos na Casa de Oswaldo Cruz a construção de um acervo de depoimentos que vêm sendo realizados ao longo do último ano. Em que pese o fato destas instituições se constituírem nos principais loci de institucionalização das ciências biológicas no país, pouco ou quase nada se sabe a respeito das cientistas mulheres que ali trabalharam, como se sua presença não tivesse deixado rastro nem registro, existindo apenas na memória de alguns contemporâneos.

$\mathrm{O}$ referido acervo integra um projeto em que, assumindo o caráter historicamente construído das relações de gênero, pretendemos analisar, no período de 1939-1968, quais as estratégias de profissionalização por elas desenvolvidas, investigando a formação educacional, o treinamento em pesquisa,

\footnotetext{
" Recebida para publicação em abril de 2003. Pesquisa desenvolvida com o apoio financeiro do $\mathrm{CNPq}$

*** Nara Azevedo é professora e pesquisadora da Casa de Oswaldo Cruz/Fiocruz; Bianca Antunes Cortes é pesquisadora da Casa de Oswaldo Cruz/Fiocruz; Luiz Otávio Ferreira é pesquisador e professor da Casa de Oswaldo Cruz/Fiocruz e professor adjunto da UERJ; Magali Romero Sá é professora e pesquisadora da Casa de Oswaldo Cruz/Fiocruz, Rio de Janeiro-RJ, Brasil. nazevedo@coc.fiocruz.br
} 


\section{Gênero e ciência}

os postos ocupados na hierarquia acadêmica $e$ a produção científica.

Estudos recentes constatam o crescimento da participação de mulheres no sistema de ciência e tecnologia (C\&T) brasileiro nos últimos vinte anos, notadamente nas instituições de ensino superior e de pesquisa, embora tal tendência não signifique uma situação de igualdade da mulher. Longe disso. O retrato mais fiel revela um desequilíbrio na participação de homens e mulheres, com sinais de discriminação em relação a estas, sinais que não são sempre explícitos e muitas vezes involuntários ou inconscientes. ${ }^{1}$ Dentre outras conclusões desses estudos uma chama a atenção em particular, a saber, a de que a educação similar atualmente não constitui mais um requisito para as mulheres partilharem posições de poder equivalentes a dos homens, sendo considerada "insuficiente para a almejada paridade entre gêneros em termos de inserção e progresso profissional, rendimentos financeiros, $e$, principalmente, de poder". ${ }^{2}$

Tal constatação cria um contraste notável entre o presente e um passado nem tão remoto assim. Até meados do século XX a educação (ou sua ausência) constituía um fator essencial de diferenciação entre homens e mulheres, sobretudo um obstáculo ao mundo da ciência.

Dessa perspectiva mais abrangente podemos observar que se a questão é a mesma - a desigualdade - ela se manifesta de forma variável no tempo. Nesse sentido, o período que se estende entre os anos 1930 e 1960 é particularmente fértil para tanto, em vista das transformações econômicas, sociais e políticas pelas quais passou a sociedade brasileira, e que atingiram tanto a

\footnotetext{
1 Ver LETA, Jacqueline. As mulheres na ciência brasileira: crescimento, contrastes e um perfil de sucesso. Estudos Avançados, 17 (49), São Paulo, 2003, pp.271284; VelHO, Lea e PROCHAZKA, Maria Viviana. No que o mundo da ciência difere dos outros mundos? www.comciencia.br/reportagens/mulheres, SBPC/Labjor, 2003; TABAK, Fanny. O laboratório de Pandora. Estudos sobre a ciência no feminino. Rio de Janeiro, Garamond, 2002.

2 Velho, L. e Prochazka, M.V. No que o mundo da ciência... Op. cit., p.1.
} 
Nara Azevedo, Bianca Antunes Cortes,

Luiz Otávio Ferreira, Magali Romero Sá

ideologia de gênero, quanto a institucionalização da ciência. A indagação que surge é: como fenômenos aparentemente distintos se articulam, potencializando-se mutuamente?

Sem pretender responder nos limites deste texto à questão tão extensa - e partindo do pressuposto de que tão mais complexa é a análise quando se percebe nas práticas discriminatórias o imbricamento entre a desigualdade promovida pelo sistema de gênero e a distinção meritocrática do sistema de estratificação social da ciência - vale destacar alguns aspectos desse processo de transformações que contribuem para a compreensão da trajetória profissional de Aída Hassón-Voloch, pesquisadora do Instituto de Biofísica da UFRJ, cuja entrevista aqui reproduzimos em parte.

Desde o final da I Guerra Mundial observa-se um movimento de mudanças no papel social da mulher, decorrente da expansão da economia urbano-industrial. A crescente participação feminina na esfera pública foi marcada pela luta em favor dos direitos jurídicos e civis - liderada pelas organizações feministas $-e$ pelo acesso a educação $e$ a profissões anteriormente vedadas a elas. Todavia, tais avanços não alteraram a hierarquia de gênero presente na sociedade brasileira, como mostra Besse $^{3}$ em seu estudo sobre o período, no qual aponta os limites e as contradições do processo de modernização capitalista. A sociedade urbana $e$ industrial se instituiu conservando valores culturais tradicionais do sistema patriarcal brasileiro, o que levaria, do ponto de vista do papel social das mulheres, a uma restrição dos efeitos potenciais da expansão das oportunidades que surgiram com a ampliação do acesso à educação secundária e superior, e ao mundo do trabalho. A revisão do sistema de gênero - provocada pelo próprio processo de modernização - representou nas palavras da autora, a "modernização da desigualdade", pois se mantiveram

3 BEsSe, Susan. Modernizando a desigualdade: reestruturação da ideologia de gênero no Brasil (1914-1940). São Paulo, Editora da USP, 1999. 


\section{Gênero e ciência}

"pressupostos arraigados e partilhados por homens e mulheres, segundo os quais as distinções entre os gêneros eram naturais e necessárias, requerendo a assimetria de poder $e$ papéis diferenciados". 4 À luz dessa ideologia de gênero, educação e trabalho feminino eram concebidos não como um meio de emancipação e realização pessoal, mas como uma extensão de seu papel familiar, ao qual se reduziam. Com base em idéias estereotipadas sobre a natureza feminina, restringiu-se tanto o ingresso das mulheres a empregos tidos como inadequados, orientando-as para "ocupações apropriadas", quanto à educação, concebida como um meio para prepará-las a atender as exigências da maternidade e da administração eficientes de seus lares. $^{5}$

Em larga medida, essa ideologia mantinha afinidade com os pressupostos que orientavam os debates sobre a educação naquele período. A reforma da educação conduzida por Gustavo Capanema em sua gestão no Ministério da Educação e Saúde (1934-1945) - de que resultaria a criação da Universidade do Brasil em 1937 (atual Universidade Federal do Rio de Janeiro) e a reforma do ensino secundário em 1942 - constituiu uma importante base de sustentação político-institucional para a redefinição do sistema de gênero. Particularmente interessante, nesse sentido, era a concepção, que presidiu essas reformas, de que o sistema educacional deveria visar o desenvolvimento de habilidades e mentalidades de acordo com os diversos papéis atribuídos às classes e categorias sociais: a elite da elite seria encaminhada para a educação superior; a elite urbana para o ensino secundário; para os jovens que comporiam o exército de trabalhadores, para a educação primária e profissional, e

4 ID., IB., p.223.

5 ID., IB., p. 123. 
Nara Azevedo, Bianca Antunes Cortes, Luiz Otávio Ferreira, Magali Romero Sá

as mulheres para o ensino doméstico e a escola normal, considerados adequados ao seu papel familiar. ${ }^{6}$

Se somarmos à segmentação por classe e sexo o fato de que as diferentes modalidades de ensino médio (profissional, normal, secundário), de acordo com a reforma ${ }^{7}$, não constiuíam uma via de acesso ao ensino superior, prerrogativa reservada ao ensino secundário - pouco freqüentado por mulheres, orientando-se a maioria das que provinham dos estratos sociais alto e médio para o ensino normal cujo diploma não era equivalente ao emitido pelo ensino secundário - percebe-se claramente as dificuldades que se interpunham para aquelas que ambicionassem alcançar a educação superior e seguir uma profissão, limitando-se, assim, a emancipação intelectual, econômica e social feminina.

Acresce que, para as mulheres que conseguissem ingressar na escola secundária, outra dificuldade se apresentava quanto à formação em ciências, pois a reforma de ensino enfatizava a

6 O Plano Nacional de Educação, elaborado a partir de um questionário distribuído, em 1936, por Gustavo Capanema a professores, estudantes, jornalistas, escritores, cientistas, sacerdotes, políticos e secretarias estaduais de educação, e enfeixado em um documento preparado pelo Conselho Nacional de Educação, apresentado, em maio de 1937 ao ministro para encaminhamento e aprovação no Congresso Nacional, previa para as mulheres um tipo de educação específica em nível médio: o ensino doméstico geral (para meninas a partir de 12 anos, com três anos de duração e certificado de dona-de-casa), o ensino doméstico industrial, que visava preparar a mulher para a indústria "dentro e fora do lar", e o ensino doméstico agrícola. Como chamam a atenção Schwartzman, Bomeny e Costa, não havia uma distinção destes cursos profissionalizantes femininos em relação aos demais destinados aos homens. A substituição do termo profissional por doméstico constituía, assim, uma clara manifestação da intenção de marcar a distinção de sexo e função. ScHWARTZMAN, Simon; Bomeny, Helena e CostA, Wanda. Tempos de Capanema. São Paulo, Paz e Terra/Editora Fundação Getúlio Vargas, 2000, p.202.

7 Como assinalam Schwartzman, BOMENy e COSTA, as concepções que presidiram a reforma dariam o tom do ensino secundário nas décadas seguintes, cujo objetivo era "produzir uma nova elite para o país, católica, masculina, de formação clássica e disciplina militar, cabendo a ela "a condução das massas", e a ela reservado o acesso ao ápice da "pirâmide educacional". ID., IB., p.218. 


\section{Gênero e ciência}

educação humanística de tipo clássico (latim e grego), em detrimento da formação técnica. Embora as ciências não tenham sido retiradas dos programas do curso secundário - sendo agregadas sob uma única disciplina, as ciências naturais -, se

substituiu o aprendizado de física, química, e ciências biológicas pelo estudo dos discursos e relatos heróicos de cidadãos e soldados na construção de impérios mesmo póstumos. Este seria o tipo de formação adequada aos futuros "condutores das massas". (...) Por algumas décadas as novas gerações estudariam, com afinco, as proezas de Caio Júlio César em suas conquistas imperiais e os discursos inflamados de Cícero contra Catilina, em defesa das instituições e privilégios dos patrícios. ${ }^{8}$

Em larga medida, a organização social do campo científico reflete tais circunstâncias sociais e culturais, em particular as limitadas oportunidades de treinamento e formação nas poucas instituições de pesquisa existentes - museus, observatórios, institutos públicos de pesquisa agrícola e de saúde. Como mostra a literatura sobre o assunto, embora essas instituições concentradas em geral no Rio de Janeiro e em São Paulo tivessem alcançado notáveis níveis de competência, elas sofriam inúmeras limitações. Não apenas não mantinham uma articulação com o ensino superior, que, por sua vez, não se organizava para o desenvolvimento da investigação experimental, como também não dispunham de financiamento exceto os modestos recursos repassados pelos ministérios e secretarias estaduais aos quais se subordinavam. Os demais auxílios eram muito instáveis e dependentes da boa vontade de um mecenas - os quais sustentavam parte expressiva da pesquisa realizada nos institutos públicos - ou de interesses de agências internacionais, como a Fundação Rockefeller, a primeira agência estrangeira a contribuir

8 ID., IB., pp.208-209, 215. 
Nara Azevedo, Bianca Antunes Cortes, Luiz Otávio Ferreira, Magali Romero Sá

para a pesquisa no país. ${ }^{9}$ Outra dificuldade residia no acesso restrito à pesquisa, sendo a única via disponível as escolas profissionais, principalmente de medicina e engenharia, além da limitada capacidade de absorção de pessoal por parte das instituições. Em geral, o ingresso dependia de relações pessoais e o treinamento, não remunerado, não assegurava uma futura contratação, em vista do reduzido quadro funcional composto por poucos cargos.

Em suma, em um ambiente caracterizado pela ausência de mecanismos sociais e institucionais apropriados, a prática científica era exercida por um grupo reduzido e extraído das elites. O background familiar constituía a influência decisiva na formação dos destinos individuais. ${ }^{10}$ Quem desejasse fazer pesquisa tinha de contar com fortuna pessoal e/ou o poder de parentes e amigos, de modo a custear suas próprias despesas, inclusive para viajar $e$ manter contatos com centros desenvolvidos de ciência. Por isso, tendeu a ser um hábito sofisticado de uma pequena elite, para quem fazer pesquisa representava mais uma vocação do que propriamente uma profissão, um atributo de uma sociedade

\footnotetext{
9 SCHWARTZMAN, Simon. Um espaço para a ciência: a formação da comunidade científica no Brasil. Brasília, Ministério de Ciência e Tecnologia/Centro de Estudos Estratégicos, 2001.

${ }^{10} \mathrm{~A}$ ausência de mecanismos impessoais e institucionalizados de socialização $e$ avaliação propiciou o surgimento no meio científico brasileiro de igrejinhas, grupos organizados como clãs ou organizações fechadas, constituídos a partir de uma liderança carismática de mentores, caracterizados como padrinhos ou padrastos, e que exerciam uma importante intermediação entre os indivíduos e sua carreira. Embora o critério de mérito fosse considerado, as relações pessoais (familisticas) predominaram na formação dos agrupamentos científicos até o aparecimento da pós-graduação, a partir da qual a titulação formal se tornou um requisito legal para o ingresso e o progresso na carreira científica. ZARUR, George. $A$ arena científica. Campinas-SP/Brasília, Autores Associados/FLACSO, 1994, pp.65,70; OliveIRA, João Batista de. Ilhas de competência. Carreiras científicas no Brasil. São Paulo, Brasiliense/CNPq, 1985, p.112.
} 


\section{Gênero e ciência}

civilizada, equivalente em importância à arte e à literatura, constituindo mais um elemento de distinção das elites. ${ }^{11}$

A configuração do campo científico nesses termos começaria a se alterar lentamente, pela mudança de perspectiva do Estado em relação à ciência, com o início de uma política de fomento à pesquisa, representada pela criação do CNPq em 1951, bem como pela expansão do sistema de ensino universitário, em virtude da demanda crescente por parte das famílias urbanas de classe média e alta.

No Rio de Janeiro, do ponto de vista das mulheres desses extratos sociais, apesar das restrições à formação científica impostas pelo ensino secundário - que, visto anteriormente, constituía a única via para o ensino superior, e voltava-se para a produção de uma elite masculina e para a educação humanística um fator importante de mudança para a expansão de oportunidades para a carreira científica foi a criação, integrada à Universidade do Brasil, da Faculdade Nacional de Filosofia (FNFI) em 1939, cujo objetivo era formar professores secundários $e$ pesquisadores. Para aquelas que ambicionassem fazer pesquisa no âmbito das ciências biológicas e biomédicas, o curso de História Natural ali instituído - originariamente pertencente à Universidade do Distrito Federal ${ }^{12}$ - se tornou uma alternativa aos cursos superiores então existentes, notadamente a Faculdade de Medicina, onde o contingente feminino era minoria e o acesso restrito, embora desde 1884 a instituição as acolhesse..$^{13}$ Uma outra

${ }^{11}$ SchWARTZMAN, Simon. Universidade e pesquisa científica: um casamento indissolúvel? In: SchwartzMAn, Simon e CASTRO, Cláudio M. (orgs.) Pesquisa universitária em questão. Campinas-SP, Editora da UNICAMP/CNPq, 1986, p.24.

${ }^{12}$ A FNFI absorveu os professores e alunos da Universidade do Distrito Federal (UDF), extinta em 20 de janeiro de 1939 pelo Decreto-lei $n^{\circ}$ 1063, assinado por Getúlio Vargas, que, logo depois, em 4 de abril, assinou o Decreto-lei no 1190 , instituindo a FNFI. SchwartzMAn, S., Bomeny, H. e Costa, W. Tempos de Capanema. Op. cit, p.229.

${ }^{13} \mathrm{O}$ acesso de mulheres ao ensino superior só foi legalmente instituído pela Reforma Leôncio de Carvalho (1879), sendo que em 1884 a Faculdade de 
Nara Azevedo, Bianca Antunes Cortes, Luiz Otávio Ferreira, Magali Romero Sá

via de acesso à educação superior que atraiu um número significativo de mulheres na época foi a Escola Nacional de Química - freqüentada por nossa entrevistada Aída HassónVoloch -, criada em 1934, vinculada ao Ministério da Agricultura e voltada para o ensino profissional de química, área que despertava grande interesse em virtude do início da expansão industrial do país. ${ }^{14}$

Parte expressiva das mulheres que ingressou nas principais instituições de pesquisa no Rio de Janeiro daquela época - Museu Nacional, Instituto de Biofísica e Instituto Oswaldo Cruz - se formaria nos cursos de História Natural e Química, que somados às transformações institucionais desencadeadas pelas novas condições materiais fornecidas pelo $\mathrm{CNPq}$, modificariam as expectativas das mulheres em relação à educação superior voltada para a realização de uma carreira científica. Esta, se por um lado, seria marcada pelas vicissitudes de uma atividade que ainda não se profissionalizara, não se distinguindo sob esse ângulo as carreiras de homens e mulheres, por outro lado, se diferenciaria

Medicina do Rio de Janeiro admitiu as três primeiras mulheres estudantes de medicina do país. AZEVEDO, Eliane e ForTUNA, Cristina. A mulher na medicina: estudo de caso e considerações. Ciência e Cultura 41(11), São Paulo, SBPC, novembro de 1989, pp.1086-1090.

${ }^{14}$ A Escola Nacional de Química do Rio de Janeiro - posteriormente incorporada à Universidade do Brasil - surgiu como um desdobramento da Escola Superior de Agricultura e Medicina Veterinária, ligada ao Departamento Nacional de Produção Mineral do Ministério da Agricultura. Em 1933, um movimento liderado por parte de vários professores dessa Escola, propôs ao ministro da Agricultura, Juárez Távora, a sua extinção e a criação de três instituições: a Escola Nacional de Química; a Escola Nacional de Agricultura e a Escola de Veterinária. A aprovação do projeto pelo ministro coincidiu com a regulamentação da profissão de químico pelo Decreto no 24.693 , de 27/07/34. AzEVEDO, Fernando. As ciências no Brasil.; FÁVERO, Maria de Lourdes. Faculdade Nacional de Filosofia. Depoimentos. Rio de Janeiro, PROEDES/UFRJ, 1992, pp.55-56; AuguSTINIS, Manlio. Engenheiros Químicos. Os motivos que obrigam seu registro nos Conselhos de Química, 2000, www.crq4.org.br/ informativo/ mar_abr_00/pagina07.html. 


\section{Gênero e ciência}

sob o efeito das ideologias de gênero, influenciando a posição das mulheres na hierarquia do establishment científico.

Dentre o contigente expressivo, mas ainda minoritário que adentrou as instituições de pesquisa cariocas em busca de novas oportunidades profissionais, identificamos Aída Hassón-Voloch, em cuja trajetória percebe-se o efeito da combinação das tendências culturais e sociais mais amplas que caracterizaram aquele período, e que balizaram o exercício da atividade científica.

Proveniente de uma família de imigrantes judeus socialmente bem posicionada, ela desfrutou o privilégio de freqüentar uma escola privada inglesa em nível secundário. Estimulada pelo pai a prosseguir sua educação, ingressou na Escola de Química em 1941, onde se formou em 1944, com a aspiração de se tornar química industrial e obter uma colocação no mercado de trabalho. Contudo, suas expectativas iniciais seriam modificadas e seu destino profissional alterado. Não apenas as oportunidades de trabalho para os químicos no âmbito da indústria eram restritas, o que a levou a conseguir apenas alguns estágios depois de formada, mas porque em um encontro fortuito - em uma viagem de regresso da Europa para o Brasil, em 1947 - entre seu pai e Carlos Chagas Filho, que se conheciam, foi convidada por este a estagiar no Instituto de Biofísica, recémcriado e onde permanece até os dias atuais.

A partir de seu relato constata-se que ela fez da carreira científica um meio de realização pessoal e intelectual, tendo sido bem sucedida nesse empreendimento. Com especialização em bioquímica na Universidade de Cambridge (1952-1953) e na Universidade de Nova York (1958), e em biofísica no próprio Instituto de Biofísica (1962-1965), onde conquistou o título de doutora em 1969, ela foi chefe de dois laboratórios (entre 1952 e 1965, o de Eletroforese, e entre 1969-1992, o de Físico-Química Biológica, que sucedeu aquele) e Chefe do Departamento de Biofísica Molecular (1973-1978).

Ministrando cursos na graduação desde 1952, e na pósgraduação a partir de 1962, onde orientou 15 dissertações de 
Nara Azevedo, Bianca Antunes Cortes, Luiz Otávio Ferreira, Magali Romero Sá

mestrado e 11 teses de doutorado, a quase totalidade de seus 65 artigos foi publicada em mais de uma dezena de revistas estrangeiras relacionadas às suas áreas de atuação: Química de Macromoléculas; Biofísica Molecular; Metabolismo e Bioenergética e Enzimologia. Ademais, o reconhecimento de seus pares veio com a sua admissão na Academia Brasileira de Ciências como membro associado em 1962, e membro titular em 1992, além de ter sido condecorada, no ano 2000, com a Ordem Nacional do Mérito Científico, concedida pelo Ministério da Ciência e Tecnologia.

Esse currículo demonstra que ela cumpriu todo os requisitos formais de uma carreira científica e acadêmica, sugerindo que ela aproveitou as oportunidades proporcionadas por um ambiente social e científico em transformação. Contudo, como transparece em seu depoimento, o entrecruzamento das estratificações de gênero e da ciência atuou no percurso de sua carreira, a qual não ficou isenta de alguma discriminação, nem sempre explícita, mas por ela percebida, e denunciada aqui, em várias passagens, sob a forma de uma bem humorada e sutil ironia, como veremos a seguir.

\section{Origem familiar e educação}

Onde a senhora nasceu?

Eu nasci em 1922 no Rio de Janeiro, na Tijuca, na rua Lúcio de Mendonça. Hoje tem lá o Hospital Israelita. Eu sou israelita, e acho graça, porque há um hospital israelita no local onde nasci. Meus pais eram da Ilha de Rhodes. Sabe onde é? No Mediterrâneo. Eles emigraram para o Brasil em 1905.

\section{Toda a família emigrou?}

A família da minha mãe inteira, mas o meu pai veio sozinho $e$ foi para a Argentina. Ele era ótico formado no Egito, e conseguiu um emprego na firma Lutz Ferrando. Mas ele já conhecia minha mãe, que morava aqui com a família dela. Na família da minha mãe, ninguém tinha se especializado em nada; eram só comerciantes 
Gênero e ciência

recém-chegados. Meu pai veio, pediu a minha mãe em casamento, e foram para a Argentina.

Sua mãe trabalhava?

Minha mãe nunca trabalhou. Eles tiveram quatro filhos na Argentina, dois rapazes e duas moças. Ela insistia para voltar para o Rio. Ela gostava do mar por causa de Rhodes. Vieram para cá e aqui nasceram mais quatro filhas, e entre elas eu. Éramos oito, mas infelizmente um morreu por botulismo com dez anos, comeu sardinha em lata. Naquele tempo era assim.

A senhora sabe por que eles emigraram?

Porque lá era uma ilha, e todo mundo queria melhorar.

As condiçôes econômicas eram ruins?

É. Naquele tempo, antes da Grande Guerra, a situação no Mediterrâneo não era boa.

Mas a familia de seu pai tinha posses. Quem sustentou seus estudos no Egito?

É. Todos viviam bem lá, mas achavam que não era bom, queriam melhorar. América, América, todo mundo falava da América. Eu falo que a América do Sul não é a América do Norte! (rindo) Mas vieram para cá e não se arrependeram. Afinal, meu pai fundou a Lutz Ferrando no Brasil e se deu bem.

A senhora comentou que seu pai estimulava as meninas a estudar?

É. Meu pai gostava muito que as mulheres estudassem. Ele dizia: "No futuro as mulheres terão que trabalhar". Eu estudei no colégio Aldridge, onde hoje é a Fundação Getúlio Vargas. Era um colégio inglês muito bom, tinha um laboratório de física, de química... Era um colégio maravilhoso! ${ }^{15}$

${ }^{15} \mathrm{O}$ Colégio Aldridge foi criado na cidade fluminense de Niterói por Messrs A.D. e Walter Leonard Aldridge. Em 1917, a sede do Colégio foi transferida para a Praia de Botafogo na cidade do Rio de Janeiro, onde funcionou até o final dos anos 40 . 
Nara Azevedo, Bianca Antunes Cortes,

Luiz Otávio Ferreira, Magali Romero Sá

Só a senhora cursou a universidade?

É. A única que seguiu uma profissão deste tipo fui eu. Eu tenho uma irmã pianista. Ela ensina música em São Paulo. A minha irmã mais velha trabalhou com meu pai e a minha irmã caçula é artista plástica. Faz muita exposição.

A senhora pode dizer então que nunca teve problemas em casa para conseguir trabalhar?

Não, nem com meu marido. Eu só casei em 1964 e continuei a trabalhar da mesma maneira. Também viajei muito a trabalho para a Inglaterra, para a França, para os Estados Unidos.

O que seu marido fazia?

Meu marido era comerciante. Ele era dono de uma loja de móveis chamada Renascença.

A senhora teve filhos?

Não. Meu marido teve filhos.

A Escola Nacional de Química e as primeiras experiências profissionais

O que lhe atraiu para a química?

O laboratório do Colégio Aldridge tinha um professor excelente. Foi por causa dele que eu me interessei pela química. No fim de 1940 eu fiz o vestibular.

Para a Faculdade Nacional de Filosofia?

Não, na Faculdade Nacional de Filosofia tinha um curso de formação de professor de química. Eu queria ser química mesmo, química industrial. Eu estudei na Escola Nacional de Química, da Universidade do Brasil, a atual Universidade Federal do Rio de Janeiro (UFRJ). Entrei em 1941 e me formei em 1944. A gente trabalhava muito no laboratório, os professores eram excelentes.

Havia professoras na Escola?

Eu não me lembro, acho que não. Havia o catedrático. Quando eu saí, algumas mulheres começaram a ingressar como assistentes.

Na sua turma havia moças? 
Gênero e ciência

Naquele tempo, era muito difícil entrar na Escola de Química. A turma era de 27 alunos. Desses cinco ou seis eram mulheres

Nessa época a senhora pensava em fazer pesquisa?

Eu nem sabia o que era pesquisa. Eles não ensinavam. O professor dava o roteiro da prática, e a gente passava o dia inteiro no laboratório. Não tínhamos que ficar lendo artigos como os estudantes de hoje. Não tinha revista, a biblioteca era pobre. Nós comprávamos os livros para estudar.

A senhora disse que não pensava em ser professora de química, $e$ desejava trabalhar como química industrial. Como a senhora conseguiu emprego após terminar a faculdade?

É, eu pensava em trabalhar como química em algum lugar. Mas não tinha emprego, tinham poucos empregos. Eu só fui trabalhar depois que me formei. Quer dizer, eu fiz alguns estágios na Produção Mineral até mesmo com o professor Fritz Feigl, um químico famoso que inventou a reação de toque. ${ }^{16}$ Ele fazia análise microquímica. Todo mundo achava aquilo o máximo, porque só se fazia análise macro. Ele fazia análise de toque numa placa de porcelana. A gente fazia reações de tudo. Era muito

${ }^{16} \mathrm{O}$ Laboratório de Produção Mineral (LPM) pertencia ao Departamento Nacional de Produção Mineral, integrado à época ao Ministério da Agricultura, e posteriormente ao Ministério de Minas e Energia. Nascido em Viena, em 15 de maio de 1891, Fritz Feigl fugiu de um campo de concentração na Bélgica. Chegando ao Brasil em 29 de novembro de 1940, radicou-se no Rio de Janeiro, onde foi convidado para trabalhar no LPM por Mário Silva Pinto, então seu diretor. Criando um Centro de Pesquisas Microquímicas - único modo à época -, Feigl foi o idealizador da análise de toque, técnica simples e eficiente, na qual provas analíticas são executadas numa só ou em poucas gotas de soluções, de preferência em pedaço grande de papel de filtro, sem utilizar qualquer instrumentação sofisticada. Abrindo um novo campo de pesquisa, com perspectivas interessantes para outros setores da Química, Feigl é reconhecido como um dos maiores químicos analíticos do século XX. A rápida divulgação da técnica de análise de toque atraiu para seu laboratório pesquisadores brasileiros $e$ estrangeiros, que ali estagiaram e fizeram cursos, tendo publicado mais de cinco centenas de trabalhos originais e 20 livros, com várias reedições. http://alchemy. iq.usp.br/agregando/vidafritz98html; http://www.iq.ufrj.br/gigantes/feigl/feigl.pdf. 
Nara Azevedo, Bianca Antunes Cortes, Luiz Otávio Ferreira, Magali Romero Sá

avançado na época. Ele era austríaco e veio fugido da Alemanha de Hitler.

Mas ele era professor da escola?

Não, ele foi logo contratado pela Produção Mineral. Estagiei um pouquinho lá com ele e depois eu fiz um estágio na seção de águas, mas era tudo estágio, emprego mesmo não tinha nenhum. Depois, eu resolvi estagiar no Instituto Nacional de Tecnologia ${ }^{17}$, porque me disseram: "Vai lá, fala com o diretor e pede um estágio não remunerado. Quem sabe sai uma vaga?" Eu fui falar com o diretor e ele disse: "Não temos vaga nenhuma!". Tinha um senhor sentado ao lado que falou: "Aqui não tem vaga pra recémformado. Passar bem". Eu saí, e aquele senhor foi atrás de mim: "Menina, você não tinha nada que falar com o diretor. Eu sou o secretário aqui do Instituto. Está todo mundo precisando de estagiário. Você quer estagiar na divisão de química orgânica?” Eu disse: "Eu quero". E ele respondeu: "Então eu vou levar você lá". Olha que coisa, o diretor nem sabia! (rindo) Aí eu fui trabalhar com o René Descartes. Vê que nome! Não tinha nada de René Descartes! Tinha um outro chamado Moacir Santos Silva que era um químico formidável. Eram todos químicos industriais. Comecei com o René Descartes fazendo uma pesquisa sobre a extração de uma substância da maçã, e me dediquei muito àquilo. Concluído o trabalho, fomos todos para um congresso em São Paulo e ele apresentou o trabalho sem mencionar que eu havia colaborado. Hoje, aqui, o estudante entra no grupo, no laboratório, e a gente

\footnotetext{
${ }^{17}$ Fundado em 1933, no âmbito do Ministério do Trabalho, Indústria e Comércio, o Instituto Nacional de Tecnologia tinha como objetivo realizar pesquisas tecnológicas com base em matérias primas nacionais para o desenvolvimento da indústria e do comércio. O primeiro diretor foi Ernesto Lopes da Fonseca Costa (1891-1952), engenheiro formado na Escola Politécnica do Rio de Janeiro, que trabalhava na Estação Experimental de Combustíveis e Minérios, criada em 1921 e vinculada ao Ministério da Agricultura. CASTRO, Maria Helena Magalhães e SCHWARTZMAN, Simon. Tecnologia para a indústria:a história do Instituto Nacional de Tecnologia, 1981, www.schwartzman.org. br/simon/publicac.htm.
} 


\section{Gênero e ciência}

põe logo o nome dele nos trabalhos. Eu falei: "Meu deus, olha só, ele nem disse que eu fiz isso tudo!" (rindo) "Eu não vou mais trabalhar com ele. Vou trabalhar com o dr. Moacir". Fui, mas ele, coitado, tinha que analisar amostras para exportação e importação. Um dia veio uma coisa assim: "Analisar 330 e tantas amostras de sulfanilamida". Sabe o que é fazer a mesma coisa 300 vezes? Falei para o meu pai: "Não é nada disso que eu quero. Eu quero fazer um trabalho bonito, bom e agradável."(rindo) E ele disse: "Ah, então não volta mais lá, não". Infelizmente o Hitler tinha matado toda a família do meu pai que estava na Europa. Um sobrinho dele foi o único sobrevivente. Ele me disse: "Eu tenho que ver como ele está. Você e sua mãe vão comigo".

\section{O ingresso no Instituto de Biofísica}

Já tinha acabado a II Guerra?

Sim, isso foi em 1946. Fui e na volta o Dr. Carlos Chagas Filho estava no navio. Pegamos uma tempestade que quase afundou o navio no estreito de Gibraltar. Uma tempestade horrível! Ficamos todos amigos. Meu pai conhecia o dr. Chagas porque a Lutz Ferrando fornecia material de pesquisa para o Instituto Osvaldo Cruz, onde o Dr. Chagas havia trabalhado. Conversa vai, conversa vem o Dr. Chagas disse: "Estou precisando muito de uma química". Eu falei: "Que sorte, eu!". E ele disse: "No dia primeiro de março - era janeiro para fevereiro de 1947 - vá falar comigo no Instituto de Biofísica”. E eu fui lá na Praia Vermelha. Eu guardo até hoje o papel que o Dr. Chagas escreveu quando eu entrei no Instituto de Biofísica.

Quando foi isso?

Em março de 1947. Está aqui o que ele escreveu:"10 de março de 1947. Estágio para experimentar: 3 meses. Horário... Atividades... Após três meses receberá um salário...". Eu acho isso muito interessante!

A senhora cumpriu essa agenda preparada pelo Dr. Chagas? 
Nara Azevedo, Bianca Antunes Cortes,

Luiz Otávio Ferreira, Magali Romero Sá

Ah! Consegui, isso demorou um mês. Eu sabia tudo! Eu já tinha aprendido na Escola de Química. Nesse período veio um professor da França e deu um curso de termodinâmica. A única que acompanhava as aulas era eu, porque ninguém sabia termodinâmica. Só na Escola de Química a gente aprendia bem. Aí o Dr. Chagas viu que na Escola de Química era diferente (rindo).

\section{Era um curso que dava uma boa formação?}

Era, a formação na Escola de Química era muito boa. Mas além de fazer o curso de eletrodinâmica, o Dr. Chagas me disse: "Por enquanto você vai ajudar o Tito Leme Lopes, que é professor da Faculdade de Farmácia, e irá fazer concurso para catedrático. Quando o José Moura Gonçalves chegar dos Estados Unidos no final do ano, você vai trabalhar com ele". Muito bem. O que ele dizia era lei. E eu fui colaborar com o trabalho de tese do Tito. Quando o Moura chegou - ele era muito extrovertido - ao saber que eu estava trabalhando com o Tito ficou uma fúria: "Quem faz tese, tem que fazer sozinho! Onde já se viu alguém fazer tese com outro?" "Foi o Dr. Chagas quem mandou, eu não vou discutir", falei para ele. Ele chegou e disse: "Ih! Trabalhar em tese dos outros... Então eu vou ajudar a fazer a tese do Lafayete Rodrigues Pereira ${ }^{18}$ e vamos ver quem ganha".

A senhora já conhecia o Moura Gonçalves?

Não, eu não conhecia. Não tinha a menor idéia! Só tinha uma moça no laboratório que o conhecia muito e me falava muito dele.

Quem era?

${ }^{18}$ Lafayete Rodrigues Pereira e Tito Enéas Leme Lopes foram colegas de turma de Carlos Chagas Filho na Faculdade de Medicina da Universidade do Brasil. Mais tarde, foram convidados por Chagas Filho para integrarem o grupo de trabalho que deu origem ao Instituto de Biofísica, da atual Universidade Federal do Rio de Janeiro. (www.schwartzman.org.br/simon/rio/biofisica.htma). O concurso a que a depoente se refere, era para a cadeira de Física Aplicada à Farmácia, sendo vencedor Tito Leme Lopes. 
Gênero e ciência

A Laura Gouvêa Vieira, era a namorada dele e depois casou com ele.

Ela era pesquisadora?

Não. Ela era uma espécie de secretária.

Havia outras mulheres trabalhando no laboratório?

Tinha a Dra. Hertha Meyer e a sua assistente, a Marysa Musacchio. Entrou também a Menuha ${ }^{19}$, mulher do Ackerman, um neurologista muito famoso na época, e muito amigo do pessoal da Biofísica. Ela trabalhava com o Antônio Couceiro. Depois vieram muitas mulheres. O Dr. Chagas não tinha essa história de discriminar nem mulher, nem preto.

Eram três mulheres naquele momento.

Que eu me lembre, sim. Tinha pouca mulher. É possível que ele achasse que não tinha função para elas. Depois vieram muitas mulheres.

Hoje tem muita mulher no Instituto?

Ih! Tem mulher adoidado! (rindo), chefe de laboratório...

Alguma mulher já foi chefe de departamento?

Eu já fui. Já teve vice-diretora ...

Do Instituto?

Ah! não.

Quem foi a primeira chefe de Departamento?

Depois que o Moura Gonçalves foi embora, eu assumi a chefia do laboratório ${ }^{20}$ e fiquei a vida inteira. Em 1972 assumi a chefia do Departamento. Fiquei mais de dez anos.

${ }^{19}$ Menhua Ackerman nos anos de 1948 e 1949 trabalhou como auxiliar do professor Antônio Couceiro no laboratório de Citologia.

${ }^{20}$ Nesse período, o Instituto de Biofísica era constituído por quatro divisões administrativas e 11 laboratórios, dentre os quais o Laboratório de Eletroforese, chefiado por Aída Hassón-Voloch desde 1952. Em 1973, passou a se denominar Laboratório de Físico-Química Biológica. Em 1999, recebeu o nome de Laboratório de Físico-Química Biológica Aída Hassón-Voloch. 
Nara Azevedo, Bianca Antunes Cortes,

Luiz Otávio Ferreira, Magali Romero Sá

Nesse período dos anos 50 havia outras chefes de laboratório?

Não, só eu e a dona Hertha. Agora, tem muitas chefes de departamento, da graduação, da pós-graduação. São elas que trabalham. Eles põem as mulheres para trabalhar, e eles para receber honrarias! (rindo)

Pode-se dizer que não havia discriminação contra a mulher no Instituto de Biofísica e nas outras instituiçóes onde a senhora trabalhou?

Não, acho que não tinha. Nem na Produção Mineral, nem no Instituto de Tecnologia nem em Manguinhos. Todas elas estavam bem.

Os homens assediavam muito as mulheres?

Não, no Instituto eu não vi. Havia muito respeito. Mas..., pensando bem, o assédio não era dos homens para as mulheres, era o contrário! (rindo)

\section{Em que laboratório a Dra. Hertha trabalhava?}

Era o de Cultura de Tecidos. Quando eu entrei a dona Hertha era independente, ela era a chefe do laboratório. Trabalhava com o tripanosoma cruzi, com parasitologia. Eu não entendia muito, porque eu era química.

Qual era a formação dela?

Ela era bióloga, não fez doutoramento nem nada, mas aqui lhe concederam um título honoris causa. Ela era alemã e foi para a Itália por causa do Hitler. Lá, acho que em Trieste, tinha um grupo muito bom. Ela falava do Dr. Otto Levi e da Rita LeviMontalcini ${ }^{21}$, que deve ser parente do Levi, eu não sei. Eu não

${ }^{21}$ Rita Levi-Montalcini, em 1986, recebeu com Stanley Cohen, o Prêmio Nobel de Fisiologia ou Medicina pelas descobertas do NGF (neural growth factor) e do EGF (epidermal growth factor). Formou-se em medicina em 1936, na Universidade de Turin, onde se especializou em neurologia e psiquiatria, e em 1946, a convite, foi para o Instituto de Zoologia da Universidade de Washington (Saint Louis, Missouri) trabalhar no laboratório de Viktor Hamburger. Neste laboratório, desenvolveu boa parte de suas pesquisas sobre o fator que promove 


\section{Gênero e ciência}

ficava fazendo pergunta a toda hora. Conheci muito a Rita Levi. Ela veio trabalhar um tempo com a dona Hertha, que tinha a Marysa como colaboradora. Tinha muita gente que vinha de vez em quando fazer uma cultura. A dona Hertha era especialista em cultura de tecidos. Todos iam aprender com ela.

\section{Ela trabalhava com microscopia eletrônica também?}

Mais tarde. Naquele momento ainda não tinha microscopia eletrônica. Ela tinha trabalhado primeiro em Manguinhos .

Com quem?

Ih! Meu deus, eu não sei dizer. O Dr. Chagas a conheceu em Manguinhos e a convidou para trabalhar com ele $e^{22}$. Quando eu cheguei no Instituto, ela já estava. Ela, a Marysa e o senhor Alexandre, o técnico que pegava o galo, tirava o sangue e fazia as culturas. Eu ficava olhando porque na Escola de Química não tinha nada disso (rindo). Era muito engraçado, porque para ir a

o crescimento e desenvolvimento de células nervosas. De 1969 até 1978 ocupou o cargo de diretora do Instituto de Biologia Celular do Conselho Nacional de Pesquisa em Roma. (http: //www.nobel.se/medicine/laureates/1986/levimontalcini-autobio.htm/). Em 1951, realizou, no laboratório chefiado por Hertha Meyer no Instituto de Biofísica, experimentos fundamentais para a demonstração do fator de crescimento neural. Por indicação de Carlos Chagas Filho, foi a primeira mulher a ingressar na Academia Pontifícia de Ciências.

${ }^{22}$ Hertha Meyer nasceu na Alemanha, onde, entre os anos de 1919 e 1921, freqüentou um curso para a formação de técnicos de biologia do Instituto de Weski, em Berlim. Com a ascensão de Hitler ao poder, migrou para a Itália, fixando, mais tarde, residência definitiva no Brasil, onde trabalhou no Laboratório de Produção de Vacinas Anti-amarílicas, instalado no Instituto Oswaldo Cruz pela Fundação Rockfeller. Quando Carlos Chagas Filho assumiu a cadeira de Física Biológica da Faculdade de Medicina da Universidade do Brasil, em 1937, logo denominada de Laboratório de Biofísica e que em 1945 viria a se transformar em Instituto de Biofísica, a convidou para chefiar o Laboratório de Cultura de Tecidos. No Brasil, ela consta dentre os pioneiros na utilização das técnicas mais modernas da microscopia de cortes ultrafinos, proporcionadas pela microscopia eletrônica, tendo sido responsável pela formação de uma geração de profissionais nos domínios destas técnicas (http://www.biof.ufrj.br/index_htm). 
Nara Azevedo, Bianca Antunes Cortes, Luiz Otávio Ferreira, Magali Romero Sá

biblioteca, lá na Praia Vermelha ${ }^{23}$ - eu gostava muito de ir a biblioteca que era boa - tinha que subir a escada, e passar por um andar intermediário, onde ficava a Anatomia e todos aqueles cadáveres! (rindo) Eu passava correndo! Era horrível!

Nessa época, o trabalho com cultura de células era uma novidade no Brasil.

Era mesmo. Foi ela quem desenvolveu, e muita gente foi aprender.

Ela deixou uma escola?

Sim, certamente. O Wanderley de Souza e o Dr. Raul Machado, que mudou do Jardim Botânico para o Instituto para trabalhar com dona Hertha, por exemplo, foram alunos dela.

A senhora falou que a Marysa era a assistente dela.

É. A Marysa era médica, casada com um bom médico. Ela vivia bem. A dona Hertha também. Vivia do salário dela, mas tinha uma indenização dos alemães devido à perseguição aos judeus. Ela morava num 'apartamentinho' muito bom no bairro Peixoto. $\mathrm{O}$ irmão dela era uma pessoa de grandes posses. Era um dos donos das Tintas Coral.

Ela nunca casou?

Não. Eu acho que ela faleceu em 1991.

No início dos anos 50, quando a senhora ia a congressos ou a outras instituiçôes, no Rio e em São Paulo, havia muitas mulheres?

Em São Paulo tinha mais. No Instituto de Tecnologia também tinha muita mulher. Eu me lembro disso. Todas químicas. A profissão era adequada (risos)...

${ }^{23}$ Na Praia Vermelha, situada no bairro carioca da Urca, funcionava a Faculdade Nacional de Medicina. 
Gênero e ciência

A medicina não era adequada para mulher?

Ser médica, não sei, ver coisas horríveis ... Tinha muita mulher na química. No Instituto de Tecnologia acho que só tinham dois homens e o resto era mulher. E também na Produção Mineral. Agora, na Escola de Química, na minha turma, não tinha muita mulher. Eu disse para você quantos tinham: eram 27 pessoas e cinco ou seis mulheres. Os homens foram todos para a Petrobrás! (rindo). No começo as mulheres, as químicas, não podiam trabalhar na Petrobrás. Diziam: "É muito perigoso". Que perigoso!? O perigo está em toda a parte. Em outros lugares, as mulheres podiam fazer concurso.

As suas colegas não se queixavam, não falavam disso entre si? Claro! Mas, quando eu viajei aos Estados Unidos, em 1957, eu conheci uma japonesa que trabalhava lá, e dizia que no Japão era muito pior. Homem e mulher iam fazer um concurso. A mulher podia ser muito melhor que o homem, mas se o homem fosse casado ele ganhava. Ela falou: "Para o Japão eu não volto por causa disso". Acabou ficando nos Estados Unidos como técnica.

Voltemos a falar do professor Moura Gonçalves. Ele tinha ido fazer pós-doutorado nos Estados Unidos?

Não, ele foi trabalhar. Trabalhou muito, publicou 12 artigos nos Estados Unidos. O Moura era ótimo, sabia demais, me ensinou muita coisa.

\section{Qual era a formação dele?}

Bioquímico. Ele veio de Minas, trabalhou com o José Baeta Viana na Universidade Federal. Nos Estados Unidos ele aprendeu muito; foi ele quem introduziu a técnica de eletroforese no Brasil. Foi com o Moura que eu aprendi a fazer eletroforese. Nós fizemos o primeiro trabalho de cromatografia em papel. Essa história é engraçada. O Moura estava trabalhando com veneno de cobra, o crotale. Quando ele estava fazendo a eletroforese, descobriu que tinha uma outra proteína além da crotoxina, que migrava para o pólo positivo, e a outra, protamina, que migrava para o negativo. 
Nara Azevedo, Bianca Antunes Cortes, Luiz Otávio Ferreira, Magali Romero Sá

Ele falou: "Faz logo a cromatografia dos aminoácidos da crotoxina para a gente ver como é". Nós fizemos tudo como manda o figurino e escrevemos o trabalho em português. Foi em 1950. Eu ainda tenho esse trabalho. Mandamos para a Ciência e Cultura. O Maurício Rocha e Silva é que era o mandão. E nada de publicar. E o Moura: "Mas que diabos, o Rocha e Silva não publica?" Daí a pouco chega uma Ciência e Cultura com um trabalho sobre cromatografia, mas quem tinha escrito era a assistente do Rocha e Silva! Ao invés de publicar nosso trabalho, ele colocou o da assistente dele, que passou a ser o primeiro trabalho de cromatografia do país (rindo).

E o trabalho de vocês, foi publicado?

Sim, saiu em outro número de Ciência e Cultura. ${ }^{24}$

$\mathrm{Na}$ época não havia muitas revistas brasileiras para vocês publicarem.

Não tinha nada. Ciência e Cultura, Anais da Academia ... e só.

Os Anais da Academia era uma revista prestigiada?

Era melhor do que agora. Quando eu estava em Cambridge, o professor que trabalhava em frente à minha bancada, tinha lido os meus trabalhos nos Anais da Academia. Hoje tem mais revistas e as pessoas ligam muito para isso. Com o peixe-elétrico começamos a publicar em revista boa, fora do Brasil, como, por exemplo, a Comparative Biochemistry and Phisiology. Quando eu fiz a minha tese de doutoramento, sobre o receptor da acetilcolina, assunto que era de impacto, publiquei na Nature. ${ }^{25}$

${ }^{24}$ Hassón-Voloch, A; GonÇAlves, J.M. Análise Cromatográfica dos Ácidos Aminados da Crotoxina. Ciência e Cultura - SBPC. Brasil, São Paulo, vol.2, no 1, 1950, pp.54-56.

${ }^{25}$ Hassón-VolOCH, A. Curare and Acetylcholine Receptor Substance. Nature, vol. 218, Londres, UK, 1968, pp.330-333. 
Gênero e ciência

\section{Viagem de estudos à Europa}

Até quando a senhora trabalhou com o Moura Gonçalves?

O Moura foi embora para a Faculdade de Medicina de Ribeirão Preto em 1952. Ele se preparou para fazer o concurso da cátedra de bioquímica, que havia sido ocupada pelo Adelino Pinto, concorrendo com o Gilberto Villela e o Paulo Lacaz, que era "filho" do Adelino. ${ }^{26}$ Eu disse para o Moura: "Não adianta você fazer esse concurso, porque quem vai ganhar é o Lacaz. Não está vendo?" Ele disse: "O Villela perder para o Lacaz? Imagina!" Perdeu para o Lacaz. Preparamos todas as práticas... nunca me esqueço... todas aquelas práticas, tudo nas prateleiras, direitinho. Mas antes do concurso, veio o Zeferino Vaz e falou para o Moura: "A Rockefeller Foundation vai fazer uma universidade em Ribeirão Preto e quer que você seja professor de bioquímica". Ele foi.

O Zeferino Vaz foi o primeiro reitor.

É. O Moura foi muito bom para Ribeirão Preto. Ele foi embora e eu fiquei.

A senhora já tinha uma agenda de pesquisa?

$\mathrm{Sim}$, o seqüenciamento da crotoxina. Eu iria fazer um estágio na Inglaterra com o Dr. Frederick Sanger, que fez a seqüência da insulina. Mas a minha ida para a Inglaterra, coincidiu com a saída do Moura do Instituto, então, eu fui para o estágio sabendo que quando eu retornasse, eu não faria, porque o Moura dizia: "A crotamina é minha, a crotoxina é minha!" Bioquímico tem mania de falar, "a minha enzima, a minha proteína...". Vocês sabiam disso? Pois é, então, eu sabia que eu não ia fazer o seqüenciamento.

${ }^{26}$ Gilberto Villela trabalhava no Instituto Oswaldo Cruz, e Paulo Lacaz era assistente de Adelino Pinto na Faculdade Nacional de Medicina. 
Nara Azevedo, Bianca Antunes Cortes,

Luiz Otávio Ferreira, Magali Romero Sá

\section{Ele continuou fazendo isso em Ribeirão?}

$\mathrm{Sim}$, mas não o seqüenciamento. Foi uma pena, a gente poderia ter feito uma colaboração. Mas naquele tempo, sei lá, não tinha ... Eu fiquei sem graça ...

Estava implícito que ele não gostaria que a senhora fizesse.

É. Mas ele podia ter aproveitado o que eu sabia.

A senhora viajou para a Inglaterra?

Eu fui primeiro para a França, em 1952, trabalhar em um laboratório de bioquímica. O Dr. Chagas achou que era bom. Fiquei durante três meses. Mas foi ruim porque eles estavam muito pobres. O Instituto de Biofísica era melhor equipado.

Depois desses três meses a senhora voltou para o Brasi?

Não, em 1953 eu fui para a Inglaterra, para o Departamento de Bioquímica de Cambridge. Passei todo o ano lá e foi uma maravilha! A Inglaterra é uma maravilha! O Dr. Sanger, o grupo, a universidade, era outra coisa.

\section{O Sanger ganhou o prêmio Nobel.}

Ganhou dois. ${ }^{27} \mathrm{O}$ Sanger estudava a estrutura da insulina. Foi a primeira vez que fizeram a estrutura de uma proteína. Durou dez anos $e$ agora fazem em um dia! (rindo) Eu aprendi muito na Inglaterra, mas era aquilo, a insulina. Quando eu voltei, não tinha o meu projeto próprio, não tinha um assunto. Eu era química industrial, não sabia nada de bioquímica. O pouco que eu sabia, tinha aprendido com o Moura. "O que é que eu vou fazer?" Olha! Foi horrivel!

\footnotetext{
${ }^{27}$ Frederick Sanger foi laureado com o Prêmio Nobel de Química em duas ocasióes: em 1958, por seu trabalho sobre a estrutura das proteínas, especialmente a insulina, e em 1980, quando dividiu a premiação com Paul Berg e Walter Gilbert, pela contribuição à determinação das seqüências de base do ácido nucléico (www.nobel.se/chemistry/laureates/).
} 
Gênero e ciência

\section{O retorno ao Brasil}

O que a senhora aprendeu não aplicou imediatamente?

Eu fiz um trabalho com um professor de reumatologia sobre umas proteínas de artrite reumatóide. Fomos todos para um congresso da Sociedade Brasileira para o Progresso da Ciência (SBPC) em Ribeirão Preto. Eu fui apresentar o trabalho que eu tinha feito na Inglaterra; o Moura Gonçalves estava nesse Congresso. Pensei que ele fosse me dizer: "Vamos fazer uma colaboração..." Mas ele queria lá dentro, ele queria desenvolver no laboratório dele...

Ele queria que a senhora fosse para lá?

Eu acho, mas ele não falou nada e eu também... Voltei e depois apareceu uma coisa... (rindo) Eu não gosto muito de falar disso, não. Fiquei uns dois anos naquilo, 1954 e 1955. Eu conheci o Lauro Solero que era professor de farmacologia da Faculdade de Medicina. Ele era muito amigo do presidente do Jockey Club. Tiveram um problema de doping no Jockey e ele conversou com o Dr. Chagas. Um dia eles me chamaram: "Nós queríamos que você aplicasse a cromatografia em papel para analisar doping, porque todo mundo faz com uma dosagem esquisitíssima. E como você sabe cromatografia, aprendeu com o Sanger, você vai fazer". Eu pensei: "Ih! Meu deus, o que eu faço?" A dona Hertha me perguntou: "O que a senhora vai fazer?" Respondi: "O que posso fazer? O Dr. Chagas está falando". Naquela época eu estava naquela situação, sem uma linha própria. Eu fiz. Foi muito bom. Aplicamos a cromatografia em papel e encontramos doping nos cavalos do Peixoto de Castro. Foi um bafafá danado! Eu tive que ir à Europa mostrar como é que funcionava o método. Fui na escola de Farmácia de Paris para demonstrar, e depois vieram os americanos aqui e o pessoal do Jockey Clube queria que eu fosse trabalhar lá. Eu falei: "Deus me livre e guarde!" (rindo) Era horrível! Graças a deus eles foram embora, e acabou esse negócio de doping. Comecei então o estudo do receptor da acetilcolina com o Dr. Chagas, utilizando o peixe elétrico como modelo 
Nara Azevedo, Bianca Antunes Cortes,

Luiz Otávio Ferreira, Magali Romero Sá

animal. Foi aí que eu comecei a trabalhar com o peixe elétrico e nunca mais larguei.

\section{A senhora estava dando aula nesse período?}

Sim, eu dava aula de biofísica. Ensinava as características do sangue, como se analisa as proteínas do sangue, os métodos físico-químicos: ph, viscosidade, densidade, isso é, físico-química, osmose, propriedades coligativas, volumetria.

Nesse período, durante os anos 50, já havia uma carreira de ensino e pesquisa na universidade?

Que nada! Não tinha.

Qual era o seu contrato de trabalho quando ingressou no Instituto?

Era verba três. Sabe como é que era? Ficava seis meses sem receber! Fazia uma fila lá na reitoria! (rindo) A verba três só pagava no final do ano (rindo). Era uma coisa horrivel! Não tinha salário mensal, não tinha décimo terceiro.... Depois apareceu o Conselho de Pesquisas e ficou melhor porque pagava regularmente. Eu tive bolsa de pesquisador-conferencista, porque tinha muito trabalho publicado e depois passei para a bolsa de pesquisador $1 \mathrm{~A}$.

\section{O trabalho com o peixe elétrico}

Como começou a desenvolver a pesquisa com o peixe-elétrico?

O Dr. Chagas queria isolar o receptor da acetilcolina, que é um neuro-transmissor, usando curare, mas não conseguimos, porque o curare é um meio inespecífico, ele combina com muitas moléculas. Nós ficamos de 1955 até 1968 procurando um outro. Umas pessoas em Taiwan encontraram um veneno da cobra Bungarus multicinetus, que é muito específico e prende no receptor da acetilcolina. Mas eles não nos deram, deram para os franceses. Aí eu deixei, não quis mais trabalhar, estava muito competitivo, muito caro, e não tinha condições. Eu tinha pouco dinheiro. 
Gênero e ciência

Nessa época a senhora teve auxilio do CNPq?

Tinha, mas não muito.

A senhora participou de algum comitê do CNPq?

Nunca, nunca me convidaram para fazer parte de nada! Só me deixaram aqui (rindo).

Com relação ao peixe elétrico, a senhora estabeleceu formas de colaboração com alguma instituição, ou pesquisadores no exterior?

Tive, com os franceses.

Onde se trabalha com peixe-elétrico?

$\mathrm{Na}$ França, Estados Unidos e Japão. Tem muita gente que trabalha.

Qual é o interesse científico no peixe elétrico?

A transmissão neuro-muscular, a origem da eletricidade humana, da eletricidade animal. Até hoje se tem uma idéia, mas não se sabe qual é a sua origem.

Essa linha de pesquisa sobre o peixe elétrico começou em 1957. A senhora nunca abandonou ou desenvolveu outra?

Eu não abandonei. No Museu Goeldi tem um professor que arranja pescador para ir a llha de Marajó pescar para a gente. Cada peixe custa trezentos reais. Agora mesmo eu encomendei um. Mas já teve um aluno da UERJ, o Mário Bernardo, que fez a tese aqui, trabalhando com substâncias radioativas para diagnóstico. Dois alunos de bioquímica da Universidade Federal do Rio Grande do Sul também fizeram tese aqui.

A senhora continuou a pesquisa mesmo depois de aposentada?

Sim. Agora tenho um aluno só. Nós estamos fazendo um trabalho bonito em colaboração com outro laboratório aqui do Instituto. 
Nara Azevedo, Bianca Antunes Cortes,

Luiz Otávio Ferreira, Magali Romero Sá

\section{Titulação e progressão na carreira}

Gostaria de voltar um pouco no tempo para saber quando e onde a senhora fez o doutorado.

Eu fiz o doutorado aqui na Biofísica, em 1963, logo que ele começou. Antes, não tinha pós-graduação. Quando a gente chegava num laboratório no exterior era uma vergonha. Eles perguntavam: "What is your title?", eu dizia "I'm chemist". Mas não era nem $\mathrm{PhD}$. Eles me convidavam para fazer o curso lá, mas teria que ficar três ou quatro anos, e eu não agüentaria ficar tanto tempo longe da minha família.

O Instituto abriu mestrado e doutorado?

É, mas eu fiz logo o doutorado porque já tinha trabalho publicado, eu ensinava... Comecei a fazer o doutorado e passei a orientar uma tese.

\section{Qual foi o assunto desenvolvido no doutorado?}

Foi sobre o receptor da acetilcolina.

A senhora nunca mais pensou em voltar para a indústria?

Não. Tanto que meu pai tinha uma loja e eu nunca quis trabalhar com ele. Eu gosto mesmo é disso aqui.

Como foi sua ascensão funcional no Instituto?

Eu fui ascendendo ...

De que maneira? Não havia barreiras?

Não, fui ascendendo. Quando vieram me perguntar se eu não ia fazer concurso para titular, o meu marido estava com câncer de pulmão e tinha um mieloma no pé. Quer dizer, eu não saía do hospital. Naquele tempo o concurso era prova prática, prova escrita, prova oral, prova disso, prova daquilo, não é como hoje que você encaminha o currículo, um memorial, e faz uma conferência que você escolhe. É uma sopa! 


\section{Gênero e ciência}

Quando a senhora foi convidada a fazer o concurso?

Foi em 1987. Ele já estava mal, e morreu em 1988. Aí eu fiquei esperando me convidarem de novo (rindo). Em 1992, eu teria que me aposentar pela compulsória, porque eu fazia 70 anos. Mas eu queria fazer o concurso.

\section{A senhora não tinha como se candidatar?}

Ninguém me convidou. Falaram: "Ah! ela já vai se aposentar, não precisa".

Quem lhe convidou em 1987?

Me lembro direitinho. Sentaram aqui o Gilberto de Oliveira Castro e o Marcelo Barcinski, e falaram: "Agora é a senhora". Mas eles queriam se candidatar.

\section{Eles queriam fazer o concurso?}

Claro! Eu falei: "Eu não posso. Como é que eu vou fazer?" O Gilberto falou: "A senhora se incomoda que eu faça?" (rindo). Eu falei: "Não. Se tem a vaga, não pode perder a vaga". Demorou muito para me convidarem. Porque não me convidaram antes? Eu já tinha dado muita aula, muito trabalho publicado, e tudo ...

A senhora acha que o casamento e a maternidade dificultam a dedicação à pesquisa?

Casamento não, mas a maternidade sim. Para toda a pessoa que trabalha fora é difícil em princípio, mas tendo quem colabore, acho que fica possível, não é?

O trabalho de pesquisa envolve muito tempo, não tem hora...

Depende. Você pode se organizar e não precisa trabalhar à noite

A senhora foi presidente da Sociedade Brasileira de Biofísica? Quando ela foi criada?

Não. O Dr. Chagas fez uma sociedade de biofísica em 1963. Funcionou durante 2 anos. Sabe como é sociedade que ninguém... Daí eu comecei a ver que tinha International Journal disso, International Journal daquilo, e tinha também o Biophysical Journal da Biophysical Society. Eu falei: "Temos que ter uma 
Nara Azevedo, Bianca Antunes Cortes,

Luiz Otávio Ferreira, Magali Romero Sá

sociedade de biofísica". Com o Wanderlei e outros professores da Biofísica reinstalamos a sociedade em 1976. A primeira reunião foi aqui no Instituto. O Elias fez um cartaz para mim, e eu coloquei no corredor (rindo). Fui secretaria geral um tempão! Todo mundo era presidente. Ninguém me convidava para ser presidente. Eu fazia tudo... ${ }^{28}$

A senhora trabalhava.

É. A Sociedade foi muito bem. Ela é itinerante. De dois em dois anos mudam o presidente e a sede. Sempre funcionou assim. Não é uma sociedade grande. O secretário tem sido aqui do Rio. Houve uma eleição em Ouro Preto e o Dr. Chagas queria que eu fosse presidente, mas o paulista não deixou.

Quem?

Um cara que desapareceu, nem existe mais. Existe mas... (rindo). Eu falei: "Dr. Chagas não brigue por causa disso. Deixe ele ser presidente. Vamos ver no que vai dar". Ele não fez nada (rindo). Aí, a presidência da Sociedade voltou para o Rio de Janeiro. Agora eu não estou lembrando porque eu me tornei presidente... Ah! Elegeram presidente o Roberto Alcântara. Ele era professor aqui da Biofísica e tinha feito a tese com o Renato Caldas. Mas ele morreu num desastre. O carro dele entrou em baixo de um caminhão. Foi horrível! Enfim, a Sociedade perdeu o presidente, e para substituí-lo, queriam que fosse alguém do Rio. Como eu havia sido sempre a secretaria geral, e fazia tudo, acharam que era eu.

A senhora se propôs?

Eu não! Eles me disseram na reunião.

${ }^{28}$ Com a partida, em 1965, do professor Carlos Chagas Filho para a França para ocupar o posto de Embaixador do Brasil junto a UNESCO - a Sociedade de Biofísica ficou inativa. Carlos Chagas retornou ao Brasil em 1970, e em 1976, foi eleito, por aclamação, presidente da Sociedade para o biênio 1976-77, sendo Aída Hassón-Voloch conduzida ao cargo de secretária geral (www.sbbf.org.br/). 
Gênero e ciência

Mas a senhora tinha algum cargo na sociedade?

Não. Eu sempre faço parte do conselho consultivo.

A sociedade tem revista própria?

Não. A revista Brazilian Journal of Medical and Biologycal Research faz parte da Sociedade de Biofísica.

A senhora integra o conselho editorial?

Não, eu já fui. É a sociedade quem nomeia os editores. Mas agora sou da comissão indicada pela Sociedade para resolver sobre a revista, como continuar, pagamento, etc. É só isso.

A senhora é membro da Academia Brasileira de Ciências?

Sou.

É membro associado ou titular?

Fui aceita como membro associado em 1962, e em 1992 me tornei titular.

A senhora sabe quem propôs o seu nome?

Não. Mas não há dúvida de que foi o Dr. Chagas.

A senhora vai as reunióes da Academia?

Eu vou quando a reunião é boa, se não, não vou. Eu já fui muito, sabe? Reuniões científicas e de ordem geral, sobre a situação dos cientistas.

Quais os outros títulos que a senhora recebeu?

Em 2000, eu fiquei admirada quando o Rocha Miranda me telefonou para dizer que eles tinham me dado a Ordem Nacional do Mérito Científico.

Quais são as suas perspectivas de trabalho?

Eu estou aposentada, mas não parei de fazer pesquisa, nem de publicar. ${ }^{29}$ No momento estou orientando um aluno. Estamos

${ }^{29}$ No ano de 2003, Aída Hassón Voloch publicou os seguintes artigos: LowE, J.; AraúJo, G. M. N.; Tavares, N. N.; Pedrenho, A.R.; Ribeiro, M.G.L.; HassónVoloch, A. Polarized distribution of $\mathrm{Na}+, \mathrm{K}+$-ATPase a-subunit isoforms in electrocyte membranes. BBA-Biomembranes, 2003; TAVARES, N.N.; FELIPPE 
Nara Azevedo, Bianca Antunes Cortes,

Luiz Otávio Ferreira, Magali Romero Sá

fazendo um trabalho bonito em colaboração com outro laboratório aqui da Biofísica. Mas o Instituto de Biofísica agora está muito diferente, eu não tenho muita perspectiva aqui. Eu tenho que pensar sobre o que fazer no futuro.

Doutora Aída gostaríamos de agradecer sua atenção em nos conceder essa entrevista.

Eu é que agradeço.

\section{Ficha Técnica}

Local: Instituto de Biofísica, Rio de Janeiro

Data: 30/09/2003 e 22/10/2003

Fitas gravadas: 3 horas

Entrevistadoras: Nara Azevedo e Bianca Antunes Cortes

Valverde, R.H.; AraúJO, G.M.N.; Hassón-VolOCH, A. Toxicity induced by Hg2+ on Choline Acetyltransferase activity from E. electricus (1.) Eletrocyte Protective effect of 2,3 Dimercapto-Propanol (BAL). Toxicological Sciences, 2003 (Sistema de Currículos Lattes/CNPq). 